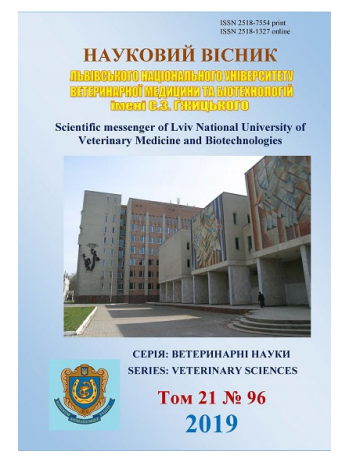

\author{
Науковий вісник Дьвівського національного університету \\ ветеринарної медицини та біотехнодогій імені С.3. Гжицького. \\ Серія: Ветеринарні науки \\ Scientific Messenger of Lviv National University \\ of Veterinary Medicine and Biotechnologies. \\ Series: Veterinary sciences
}

\title{
Features of the course and treatment of chronic catarrhal gingivitis in dogs
}

\author{
N.M. Khomyn ${ }^{1}$, A.R. Mysak ${ }^{1}$, S.V. Tsisinska ${ }^{1}$, V.V. Pritsak ${ }^{1}$, N.V. Nazaruk ${ }^{1}$, M.M. Khomyn ${ }^{2}$ \\ ${ }^{1}$ Stepan Gzhytskyi National University of Veterinary Medicine and Biotechnologies Lviv, Ukraine \\ ${ }^{2}$ Institute of Animal Biology NAAS, Lviv, Ukraine
}

Article info

Received 02.10.2019

Received in revised form 03.11 .2019

Accepted 04.11.2019

Stepan Gzhytskyi National University of Veterinary Medicine and Biotechnologies Lviv,

Pekarska Str., 50, Lviv,

79010, Ukraine.

Tel.: +38-067-894-17-12

E-mail:nadiakhomyn@ukr.net

Institute of Animal Biology of NAAS, Stusa Str., 38, Lviv,

79000, Ukraine.
Khomyn, N.M., Mysak, A.R., Tsisinska, S.V., Pritsak, V.V., Nazaruk, N.V., \& Khomyn, M.M. (2019). Features of the course and treatment of chronic catarrhal gingivitis in dogs. Scientific Messenger of Lviv National University of Veterinary Medicine and Biotechnologies. Series: Veterinary sciences, 21(96), 53-57. doi: 10.32718/nvlvet9609

Chronic catarrhal gingivitis is a polyetiological disease, in the pathogenesis of which the main role belongs to the microorganisms of the oral cavity of the dog, odontogenic deposition in the form of dental plaques and tartar. These depositions, due to the constant irritation of the gums cause disease, the main clinical signs of which are halitosis, poor feed intake, swelling and bleeding gums. The problem of chronic catarrhal gingivitis treatment is devoted to numerous inverstigations, the priority of which is a comprehensive approach, which includes a step-by-step influence on the etiological and pathogenetic mechanisms of the disease. Therefore, the purpose of the work is to study the features of the course of chronic catarrhal gingivitis and to develop a method for the treatment of dogs with dental disease. The prevalence gingivitis in dogs, the influence of microflora on the condition of the oral cavity in chronic catarrhal gingivitis, was investigated the symptomatology of the disease, was established the value of clinical indicators and dental indices and tests, which reflect the intensity and nature of the inflammatory process in the gums of dogs suffering from chronic catarrhal gingivitis, and a method of treating dental animals was developed. The results of the inverstigations showed that the application by application to the mucous membrane of gums $0.05 \%$ solution of chlorhexidine and a gel composition of $4 \%$ chitosan ascorbate with metronidazole, and also feeding once a day for 30 days of the vitamin-mineral supplement "Canvit Biocal Plus" in the complex treatment of dogs with chronic catarrhal gingivitis helps to reduce the recovery period of dogs by 5 days.

Key words: teeth, chlorhexidine, chitosan ascorbate, metronidazole, vitamin-mineral supplement, tartar, microflora, inflammation.

\section{Особливоті перебігу та лікування хронічного катарального гінгівіту у собак}

\author{
Н.М. Хомин ${ }^{1}$, А.Р. Мисак ${ }^{1}$, С.В. Цісінська ${ }^{1}$, В.В. Прицак ${ }^{1}$, Н.В. Назарук ${ }^{1}$, М.М. Хомин ${ }^{2}$ \\ ${ }^{1}$ Львівський національний університет ветеринарної медицини та біотехнологій імені С.3. Гжицького, м. Львів, \\ Україна \\ ${ }^{2}$ Інститут біології тварин НААН, м. Львів, Украӥна
}

\footnotetext{
Хронічний катаральний гінгівіт - це поліетіологічне захворювання, в патогенезі якого основна роль належить мікроорганізмам ротової порожнини собаки, одонтогенним відкладенням у вигляді зубних бляшок $і$ зубного каменю. Ці відкладення внаслідок постійного подразнення ясен викликають захворювання, основними клінічними ознаками якого є галітоз, порушення прийому корму, набряк і кровоточивість ясен. Проблемі лікування хронічного катарального гінгівіту присвячені численні дослідження, приорітетним принципом яких є комплексний підхід, щчо включає поетапний вплив на етіологічні фактори та патогенетичні механізми захворювання. Тому метою роботи було вивчення особливостей перебігу хронічного катарального гінгівіту та розроблення методу лікування стоматологічно хворих собак. Встановлено поширеність гінгівітів у собак, вплив мікрофлори на стан ротової порожнини собак за хронічного катарального гінгівіту, досліджено симптоматику захворювання, встановлено величину клінічних
} 
показників та стоматологічних індекси і проб, які відображають інтенсивність та характер запального процесу в яснах собак, хворих на хронічний катаральний гінгівіт, розроблено метод лікування стоматологічно хворих тварин. Результати досліджень показали, що застосування шляхом нанесення на слизову оболонку ясен 0,05\% розчину хлоргексидину та гелевої композиції 4\% аскорбату хітозану з метронідазолом, а також згодовування 1 раз на добу протягом 30 діб вітамінно-мінеральної добавки “Canvit Biocal Plus” у комплексному лікуванні собак за хронічного катарального гінгівіту сприяє скороченню періоду одужання собак на 5 діб.

Ключові слова: зуби, хлоргексидин, аскорбату хітозан, метронідазол, вітамінно-мінеральна добавка, зубний камінь, мікрофлора, запалення.

\section{Вступ}

Відомо, що хвороби пародонта складають найбільшу групу захворювань ротової порожнини у собак. Вони є однією з основних причин втрати зубів, зниження функціональних можливостей зубощелепної системи, виникнення деформацій, формування хронічних вогнищ поза ротовою порожниною, сенсибілізації організму та розвитку різних соматичних захворювань (Frolov, 2004; Vasileva; 2006, Kuhtyn, 2009). Питанню вивчення пародонтопатій, зокрема гінгівіту у собак та розробці методів лікування хворих тварин як найбільш важливих і складних проблем у ветеринарній стоматології присвячені роботи багатьої вітчизняних і зарубіжних вчених (Guselnikov, 2003; Frolov, 2008; Spirina, 2016). Здебільшого захворювання супроводжуються складними і глибокими порушеннями на морфологічному рівні та системними змінами біохімічних, імунологічних, ендокринних реакцій (Timofeev, 2007; Frolov, 2009; Khomyn \& Kostyshyn, 2015; Khomyn et al., 2016).

Загалом лікування стоматологічно хворих собак проводять за принципом індивідуального підходу до тварини з урахуванням даних загального та стоматологічного статусу. Лікування має бути комплексним, тобто полягати в усуненні основної причини виникнення хвороби та проведенні їі лікування, знятті зубного каменя (Kulinich \& Sarantseva, 2011; Khomyn et al., 2017), іригації слизової оболонки ротової порожнини та ясен антисептичними препаратами і висушування марлевими тампонами ураженої ділянки 3 подальшим проведенням лікування безпосередньо стоматологічного захворювання (Vasileva, 2006; Frolov, 2008).

Однак питання розробки і впровадження у практику ветеринаної медицини нових ефективних методів і засобів санації ротової порожнини тварин та лікування собак за пародонтопатій, зокрема гінгівіту хронічного перебігу, залишається актуальним.

Мета роботи. Вивчити особливості перебігу хронічного катарального гінгівіту та розробити лікування стоматологічно хворих собак.

\section{Матеріал і методи досліджень}

Для проведення досліджень було сформовано дві групи тварин 3 хронічним катаральним гінгівітом по 5 собак у кожній (контрольна і дослідна), підібраних за принципом аналогів щодо віку та характеру запального процесу. Лікування собак обох груп починали зі зняття зубного каменю та шліфування зубів. На ясна тварин контрольної групи наносили 0,02\% фура- цилін і йоддицерин, а дослідної - 2 рази на добу наносили $0,05 \%$ розчин хлоргексидину та гелеву композицію 4\% аскорбату хітозану з метронідазолом, а також 1 раз на добу протягом 30 діб згодовували вітамінномінеральну добавку “Canvit Biocal Plus” iз розрахунку 1таблетка на 5 кг ваги тіла тварини.

Клінічні дослідження, 3 урахуванням скарг власників тварин на неприємний запах з ротової порожнини собак, кровоточивість ясен у них під час чищення зубів та за прийому твердої їжі, включали встановлення змін з боку слизової оболонки, тобто болючості, гіперемії, припухлості, кровоточивості, галітозу та зубоясневої борозни, які виявляли шляхом огляду i пальпації; за інструментального обстеження не виявлено порушень цілісності зубоясенного прикріплення.

Ефективність лікування визначали за станом гігієни ротової порожнини та місцевого імунітету.

Для вивчення гігієнічного стану ротової порожнини та поширення патологічного процесу в тканинах пародонта застосовували математичні показники у вигляді пародонтальних індексів та проб (Kutsevlyak \& Lahtin, 2002). Використання перерахованих вище критеріїв дозволяє об'єктивно визначити наявність та інтенсивність запалення в тканинах ясен.

3 метою вивчення якісного і кількісного складу мікрофлори досліджували такі біотопи: ротова рідина, зубний наліт, зубояснева борозна, слизові оболонки язика, ясен, піднебіння. Ідентифікацію виділених мікроорганізмів до родів проводили згідно з визначником бактерій Берджі (Holt et al., 1997). Визначення вмісту кислої фосфатази, білка та лізоциму проводили згідно із загальноприйнятими методиками (Komarov et al., 2001; Denisenko \& Kesareva, 2011). Клінічні дослідження проводили до та на 3, 5, 7, 10 добу лікування, а стоматологічні, бактеріологічні та імунологічні - до і на 3, 7, 10 добу лікування.

Отримані числові дані обробляли за допомогою стандартного пакету статистичних програм Microsoft EXCEL.

\section{Результати та їх обговорення}

Встановлено, що серед стоматологічних хвороб у собак найчастіше виявляють гінгівіти, які складають $42 \%$ випадків, дещо менший відсоток, а саме 28\% становлять пародонтити і лише 18,0 та 12,0\% складають відповідно стоматити і переломи зубів. Причому на хронічний катаральний гінгівіт припадає 37\% серед інших форм цього захворювання ясен.

Відомо, що мікрофлора ротової порожнини відіграє значну роль у розвитку запальних процесів у тканинах пародонта. Це багатокомпонентна система, що 
перебуває в складних метаболічних і біохімічних відношеннях між собою та 3 макроорганізмом, а також відіграє значну роль у розвитку запальних процесів у тканинах пародонта. Розвиток запалення у цих тканинах визначається ступенем активації умовнопатогенної мікрофлори пародонта і станом бар'єрів, які захищають від колонізації цього біотопу (Vasileva, 2006). Результати дослідження кількості МАФАнМ у біотопах ротової порожнини собак за хронічного катарального гінгівіту наведені у таблиці 1 .
Встановлено, що досліджувані біотопи ротової порожнини собак за кількісним вмістом МАФАнМ розмістилися від більшого обсіювання до меншого у такому порядку: зубні відкладення - 3 вмістом мікроорганізмів $10^{9} \mathrm{KУO} / \mathrm{cm}^{3}$ змиву, ротова рідина $\mathrm{x} 10^{7} \mathrm{KУО} / \mathrm{cm}^{3}$, слизова оболонка язика $-10^{5} \mathrm{KУO} / \mathrm{cm}^{3}$, зубояснева борозна $-10^{4}$, слизова оболонка ясен $-10^{3}$ і слизова оболонка піднебіння - 3 вмістом мікроорганізмів $10^{2} \mathrm{KУO} / \mathrm{cm}^{3}$ змиву.

\section{Таблиця 1}

Кількість МАФАнМ у біотопах ротової порожнини собак за ХКГ (M $\pm \mathrm{m}, \mathrm{n}=5)$

\begin{tabular}{|c|c|c|}
\hline \multirow{2}{*}{ Досліджуваний біотоп } & \multicolumn{2}{|c|}{ Групи } \\
\hline & Контрольна (клінічно здорові) & Дослідна (хворі на ХКГ) \\
\hline ротова рідина, $\mathrm{x} 10^{7} \mathrm{KУO} / \mathrm{cm}^{3}$ & $1,26 \pm 0,10$ & $2,58 \pm 0,25 * *$ \\
\hline зубні відкладення, х109 КУО/см ${ }^{3}$ & $1,15 \pm 0,12$ & $2,56 \pm 0,19 * * *$ \\
\hline 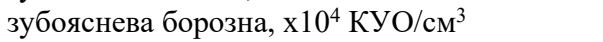 & $2,57 \pm 0,17$ & $4,08 \pm 0,26^{* *}$ \\
\hline слизова оболонка язика, $\mathrm{x} 10^{5} \mathrm{KУO} / \mathrm{cm}^{3}$ & $4,50 \pm 0,35$ & $5,82 \pm 0,30^{*}$ \\
\hline слизова оболонка ясен, $\times 10^{3} \mathrm{KУО} / \mathrm{cm}^{3}$ & $1,84 \pm 0,14$ & $3,31 \pm 0,22 * * *$ \\
\hline слизова оболонка піднебіння, х10² КУО/ $\mathrm{cm}^{3}$ & $2,32 \pm 0,18$ & $2,50 \pm 0,25$ \\
\hline
\end{tabular}

Примітка: ${ }^{*}-\mathrm{P}<0,05,{ }^{*}-\mathrm{P}<0,01,{ }^{* * *}-\mathrm{P}<0,001-$ вірогідна різниця порівняно 3 показниками контрольної групи

У ротовій рідині, яка є зв’язковою ланкою між біотопами ротової порожнини, кількість мікроорганізмів збільшилась у 2 рази. У зубних відкладеннях кількість мікроорганізмів збільшилась у 2,23 разу, в зубоясневій борозні - у 1,59 разу, на слизовій оболонці язика у 1,29 разу, на слизовій оболонці ясен - у 1,80 разу. Найменше зросла кількість мікроорганізмів за хронічного катарального гіогівіту на слизовій оболонці піднебіння. Так, різниця між контрольною і дослідною групами була більшою в 1,1 разу. Отже, хронічний катаральний гінгівіт у собак характеризується збільшенням кількості мікроорганізмів в основних біотопах ротової порожнини.

Дослідженнями встановлено, що до початку лікування загальний стан тварин обох груп був пригнічений. На їхніх зубах знаходиться зубний наліт жовтуватого кольору, що охоплює майже половину ікла. У ділянці зубоясневої борозни нижнього ікла спостерігається відкладання над'ясневого каменю жовтокоричневого кольору. Характерним є кровоточивість за незначного подразнення ясен, біль та галітоз. Маргінальна і верхівка альвеолярної ділянки ясен гіперемійовані, набряклі, що свідчить про наявність запального процесу. У ділянці гінгівальної борозни ікла нижньої щелепи міститься псевдокишеня, глибина якої становить близько 2-3 мм.

За гінгівіту не порушується цілість зубо-ясенного 3'єднання, однак за рахунок набряклості міжзубних сосочків, збільшення їх обсягу створюється поглиблення ясневої борозни, в яку потрапляють рештки корму, і згодом заглиблення розширюється, заноситься патогенна мікрофлора, яка поступово руйнує пародонт та зуб загалом (Guselnikov, 2003).

Відомо, що мікрофлора ротової порожнини відіграє важливу роль у збереженні здоров'я тварин. Зокрема, у хворих тварин обох груп кількість МАФАнМ у зубних відкладеннях була великою, що можна вважати однією з причин виникнення захворювання за високих показників активності кислої фосфатази як маркера стану клітинних мембран та вмісту білка у ротовій рідині - як показника запальних процесів за низької конценгтації лізциму.

Через 3 доби після зняття над'ясневого зубного каменю і застосування запропонованого лікування у собак дослідної групи припухлість, болючість, місцева температура були незначні за слабо вираженого почервоніння та незначно вираженого галітозу, що свідчить про зменшення ознак запалення, тимчасом як у собак контрольної групи ще зберігалися ознаки гострого запального процесу.

Кількість МАФАнМ у зубному нальоті собак дослідної групи у зменшилась 1,97 разу та тлі зменшення концентрацї в інших біотопах ротової порожнини (рис. 1), знизилась активність кислої фосфатази на $11,7 \%$, зменшився вміст білка у ротовій рідині - на $32,7 \%$ за збільшення концентрації лізоциму на 10,3\%, тимчасом як щодо початку лікування ці показники змінилися відповідно на 26,4, 37,0 та 13,0\% (табл. 2).

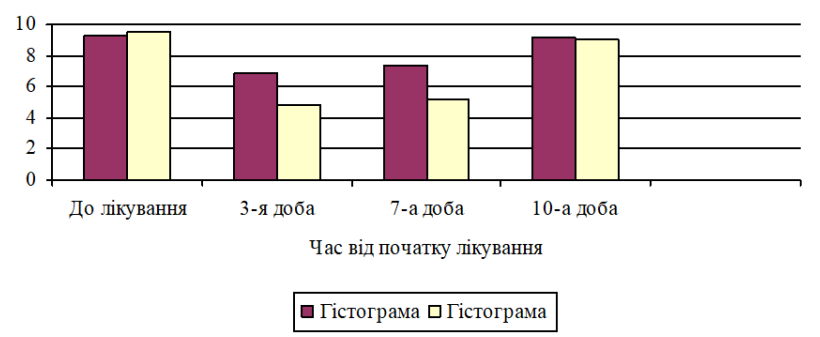

Рис. 1. Кількість МАФАнМ у зубному нальоті собак, хворих на хронічний катаральний гінгівіт, за різних методів лікування 
Таблиця 2

Динаміка біохімічних та імунологічних показників за хронічного катарального гінгівіту у собак, $\mathrm{M} \pm \mathrm{m}, \mathrm{n}=5$

\begin{tabular}{|c|c|c|c|c|}
\hline \multirow[t]{2}{*}{ Показники } & \multirow[t]{2}{*}{ Групи } & \multicolumn{3}{|c|}{$\begin{array}{l}\text { Активність кислої фосфатази і вміст білку у ротовій рідині собак із } \\
\text { ХКГ, } \mathrm{M} \pm \mathrm{m}, \mathrm{n}=4\end{array}$} \\
\hline & & До лікування & 3 доба & 7 доба \\
\hline \multirow{2}{*}{$\begin{array}{l}\text { Кисла фосфатаза, } \\
\text { мккат/л }\end{array}$} & K & $0,84 \pm 0,06$ & $0,60 \pm 0,04$ & $0,51 \pm 0,03$ \\
\hline & Д & $0,72 \pm 0,03$ & $0,53 \pm 0,01 * *$ & $0,29 \pm 0,01 * * *$ \\
\hline \multirow{2}{*}{ Вміст білка, г/л } & K & $3,12 \pm 0,20$ & $2,69 \pm 0,20$ & $1,52 \pm 0,04$ \\
\hline & Д & $2,87 \pm 0,14$ & $1,81 \pm 0,12^{* * *}$ & $1,33 \pm 0,02 * * *$ \\
\hline \multicolumn{5}{|c|}{ Показники місцевого імунітету ротової порожнини собак із ХКГ у ротовій рідини, $\mathrm{M} \pm \mathrm{m}, \mathrm{n}=5$} \\
\hline \multirow{2}{*}{ Лізоцим, од./мл } & K & $8,3 \pm 0,28$ & $8,7 \pm 0,20$ & $9,1 \pm 0,03$ \\
\hline & Д & $8,5 \pm 0,21$ & $9,6 \pm 0,04 * * *$ & $10,2 \pm 0,42 *$ \\
\hline
\end{tabular}

Через 7 діб від початку лікування собак за хронічного катарального гінгівіту спостерігалися слабо виражені ознаки місцевого запального процесу за відсутності галітозу, тимчасом як у собак контрольної групи збереглися незначна припухлість ясен, їх почервоніння, болючість, галітоз, що свідчить про збереження ознак запалення.

Кількість мікроорганізмів у зубному нальоті, порівняно із 3-ю добою лікування, у тварин дослідної групи зменшилась на 9,62\%, проте була нижчою щодо початку лікування в 1,81 раза. Активність кислої фосфатази знизилась на 59,7\%, вміст білка в ротовій рідині - на 53,7\% за збільшення концентрації лізоциму на 20,0\%, тимчасом як щодо контролю ці показники змінились відповідно на 43,1, 12,5 та 12,1\%.

На 10-у добу лікування загальний стан собак дослідної групи задовільний, ознаки місцевого запально- го процесу відсутні, тимчасом як схожі клінічні ознаки у контрольної групи спостерігались лише на 15 добу.

Загалом лікування собак дослідної групи тривало 10 діб, тобто завершилось на 5 діб швидше, ніж у тварин контрольної групи.

Відомо, що об'єктивну інформацію про перебіг хвороби можна отримати, подавши клінічні ознаки хвороби у вигляді числових виразів та спеціальних індексів, оскільки вони відображають інтенсивність запалення в яснах стоматологічно хворих собак (табл. 3).

Встановлено, що на 3-ю добу лікування йодне число Свракова, яке характеризує пробу ШиллераПисарєва знижувалося на 17,7\%, а порівняно із початком лікування - на 38,8\%. На 7-му добу проба була негативною, тобто глікоген у яснах був відсутній.

\section{Таблиця 3}

Динаміка показників індексів гігієни та клінічного стану пародонта у собак, хворих на хронічний катаральний гінгівіт, $\mathrm{M} \pm \mathrm{m}, \mathrm{n}=5$

\begin{tabular}{|c|c|c|c|c|}
\hline \multirow{2}{*}{ Група } & \multirow{2}{*}{ До лікування } & \multicolumn{3}{|c|}{ Доба від початку лікування } \\
\hline & & 3 & 7 & 10 \\
\hline \multicolumn{5}{|c|}{ Проба Шиллера-Писарєва (йодне число Свракова) } \\
\hline контрольна & $2,67 \pm 0,22$ & $1,87 \pm 0,19$ & $0,71 \pm 0,05$ & Негативна \\
\hline лослідна & $2,78 \pm 0,20$ & $1,54 \pm 0,10$ & Негативна & Негативна \\
\hline \multicolumn{5}{|c|}{ Індекс кровоточивості } \\
\hline контрольна & $1,71 \pm 0,06$ & $0,30 \pm 0,01$ & 0 & 0 \\
\hline лослідна & $1,40 \pm 0,04$ & 0 & 0 & 0 \\
\hline \multicolumn{5}{|c|}{ Папілярно-маргінальний індекс } \\
\hline контрольна & $33,2 \pm 2,69$ & $28,7 \pm 1,70$ & $8,0 \pm 0,32$ & 0 \\
\hline лослідна & $39,0 \pm 3,12$ & $20,6 \pm 0,78$ & 0 & 0 \\
\hline \multicolumn{5}{|c|}{ Індекс гігієни Green-Vermillion } \\
\hline контрольна & $2,39 \pm 0,12$ & 0 & 0 & 0 \\
\hline лослідна & $2,430 \pm 0,10$ & 0 & 0 & 0 \\
\hline
\end{tabular}

За проведеного лікування хворих собак знижувався й індекс кровоточивості ясен, що свідчить про значне зниження проникливості ясневих кровоносних судин. Так, на третю добу цей показник був негативний.

Про позитивний ефект лікування свідчить і зниження папілярно-маргінального індексу, який відображає інтенсивність запального процесу в яснах за хронічного катарального гінгівіту у собак. Проведене лікування призвело до зниження індексу порівняно із початком лікування на 3-тю добу в 1,9 разу, а порівняно 3 контрольним показником величина індексу зменшилася на 28,2\% за негативної реакції на 7-у добу.

Індекс гігієни Green-Vermillion, за якого на досліджуваних поверхнях спершу визначають зубний наліт, згодом зубний камінь і за сумою двох показників визначають показник групового індексу та встановлюють рівень гігієни, після застосування розроблено- 
го методу лікування був негативний, що свідчить про хорошу гігієну ротової порожнини.

Отже, аналізуючи результати індексної оцінки ефективності проведеного лікування собак з хронічним катаральним гінгівітом, встановили, що нанесення на ясна собак стоматологічно хворих тварин $0,05 \%$ розчину хлоргексидину та гелевої композиції 4\% аскорбату хітозану з метронідазолом, а також 1 раз на добу протягом 30 діб згодовування вітамінномінеральної добавки “Canvit Biocal Plus” сприяє швидшому одужанню собак, що проявляється негативною пробою Шиллера-Писарєва, припиненням кровоточивості ясен i зниженням папілярно-маргінального індекса.

\section{Висновки}

1. Серед стоматологічних хвороб у собак найбільший відсоток, а саме 42, складають гінгівіти; на хронічний катаральний гінгівіт припадає 37\%.

2. За хронічного катарального гінгівіту в собак спостерігається збільшена кількість патогенної мікрофлори у біотопах ротової порожнини, а також підвищена активність кислої фосфатази, збільшена концентрація білка за низького вмісту лізоциму в ротовій рідині.

3. Нанесення на слизову оболонку ясен собак за хронічного катарального гінгівіту $0,05 \%$ розчину хлоргексидину та гелевої композиції 4\% аскорбату хітозану з метронідазолом, а також 1 раз на добу протягом 30 діб згодовування вітамінно-мінеральної добавки "Canvit Biocal Plus" iз розрахунку 1 таблетка на 5 кг ваги тіла тварини сприяє зменшенню ознак запального процесу та скороченню періоду лікування на 5 діб.

Перспективи подальших досліджень. Дослідження будуть спрямовані на розробку нових заходів профілактики хронічного катарального гінгівіту в собак.

\section{References}

Denisenko, V.N., \& Kesareva, E.A. (2011). Klinicheskaya interpretatsiya biohimicheskih pokazateley syivorotki krovi sobak i koshek. M.: Izd: Kolos (in Russian).

Frolov, V.V. (2004). Bolezni zubov i slizistoy obolochki polosti rta u sobak. M.: Akvarium-LTD (in Russian).

Frolov, V.V. (2008). Parodontologiya. Osnovnyie problemyi diagnostiki i lecheniya parodonta u sobak. Veterinarnaya klinika, 10(77), 34-35 (in Russian).
Frolov, V.V. (2009). Ostryie i hronicheskie bolezni paradonta u sobak. Trudy VIII Mizhnarodnoyi naukovopraktychnoyi veterynarnoyi konferentsiyi z problem dribnyh tvaryn. Uman, 154-159 (in Russian).

Guselnikov, E.V. (2003). Zabolevaniya organov rotovoy polosti. Vestnik veterinarnoy meditsinyi, 4, 18-20 (in Russia).

Holt, Dzh., Krig, N., \& Snit, P. (1997). Opredelitel bakterij Berdzhi. T. 1. M.: Mir. http://www.rfbr.ru/rffi/ru/books/o_59110 (in Russian).

Khomyn, N. M., \& Kostyshyn, L. (2015). Peculiarities of periodontitis in dogs. Scientific Messenger of LNU of Veterinary Medicine and Biotechnologies, 17(1), 213220. https://nvlvet.com.ua/index.php/journal/article/ view/249.

Khomyn, N., Mysak, A., Iglitskej, I., Pritsak, V., \& Semeniyk, N. (2017). Treatment of dogs for periodontal diseases. Scientific Messenger of LNU of Veterinary Medicine and Biotechnologies, 19(82), 170-174. https://nvlvet.com.ua/index.php/journal/ article/view/1359.

Khomyn, N.M., Mysak, A.R., Iglitskej, I.I., Nazaruk, N.V., \& Grymak, Y.I. (2016). Spreading and reason of parodont disease rise in dogs and cats. Scientific Messenger of LNU of Veterinary Medicine and Biotechnologies, 18(1), 194-198. https://nvlvet.com.ua/ index.php/journal/article/view/72.

Komarov, F.I., Korovin, B.F., \& Menshikov, V.V. (2001). Biohimicheskie issledovaniya $\mathrm{v}$ klinike. M., Elista: APP "Dzhangar", 35-40 (in Russian).

Kuhtyn, M.D (2009). Mikrobni bioplivky - yavysche isnuvannya ta zahystu mikroorganizmiv. Veterynarna medytsyna Ukrayiny, 10, 20-21 (in Ukrainian).

Kulinich, S.M., \& Sarantseva, N.K. (2011). Porivnyaina efektivnist fizichnogo ta mehanichnogo metodiv znyattya zubnogo kamenyu u dribnyh tvaryn za paradontytu. Visnyk Poltavskoyi derzhavnoyi agrarnoyi akademiyi, 2, 108-111 (in Ukrainian).

Kutsevlyak, V.F., \& Lahtin, Yu.V. (2002). Indeksnaya otsenka parodontalnogo statusa. Uchebnometodicheskoe posobie. Sumyi: VVP “MrIya-1" LTD (in Russian).

Spirina, A.S. (2016). Stomatologicheskie zabolevaniya. Bolezni parodonta u sobak i koshek. Mir veterinarii, 4, 50-54 (in Russian).

Timofeev, C.B. (2007). Stomatologiya zhivotnyih. M.: Agrovet (in Russian).

Vasileva, M.B. (2006). Vospalitelnyie zabolevaniya parodonta u sobak. Avtoref. dis... na soisk. nauch. stepeni kand. vet. nauk: spets. 16.00.05 "Veterinarnaya hirurgiya". Sankt-Peterburg (in Russian). 